\title{
Capacity payments to secure electricity supply? On the future of Germany's power market design
}

\author{
Paul Lehmann ${ }^{1 *}$, Robert Brandt ${ }^{2}$, Erik Gawel ${ }^{1,3}$, Sven Heim ${ }^{4}$, Klaas Korte ${ }^{1}$, Andreas Löschel ${ }^{5}$, Philipp Massier ${ }^{4}$, \\ Matthias Reeg ${ }^{6}$, Dominik Schober ${ }^{4}$ and Sandra Wassermann ${ }^{7}$
}

\begin{abstract}
Although the objectives of the Energiewende (energy transition) are broadly accepted in Germany, the practical ways of achieving them remain highly contentious. In particular, the question of whether and how security of supply can be guaranteed over the course of this profound transformation of the energy system is currently the subject of controversy in the scientific and public debate. Recently, calls for additional payments to power plant operators for providing generation capacity have grown increasingly loud. But the introduction of capacity payments of this sort could have far-reaching consequences for the future organisation of Germany's electricity supply. Therefore, the political decision on this issue - which is scheduled for this year - should not be made without a sound scientific analysis. Basically, measures aimed at guaranteeing security of supply must address the possible causes of capacity shortages as broadly as possible. When designing such measures, besides security of supply, additional objectives such as cost-effectiveness and the environmental and social acceptability of electricity supply should also be taken into account. Capacity payments only partially meet these requirements. Moreover, once introduced, they are difficult to adapt, or revise even, to suit changing framework conditions. This is particularly problematic in view of the current lack of clear evidence for future security of supply problems. Therefore, introducing capacity payments at this point in time would not appear to be constructive. It would make more sense to introduce instead a mix of measures which would strengthen the electricity market, create conditions for feeding in electricity from renewable energy sources as and when required, and set incentives for the expansion of grid capacity, storage systems and demand side management. Should security of supply still appear uncertain under these changed framework conditions, the introduction of a strategic reserve, which would be held by the regulatory authority or the transmission system operator, is recommended - not, however, the creation of an entirely new, additional market segment in the form of a capacity market.
\end{abstract}

Keywords: Capacity mechanism; Capacity market; Electricity market; Energiewende; Energy transition; Germany; Policy mix; Renewable energies; Strategic reserve

\section{The discourse on security of supply in Germany ${ }^{a}$} Recently, fears that a secure supply of electricity might be jeopardised in the course of the German Energiewende have increasingly been expressed [1-3]. The reasons for these concerns are varied. On the one hand, the share of intermittent renewable energy sources (wind and solar) has been increasing steadily [4]. As a consequence, the challenge of balancing not only fluctuating demand but also a partly volatile energy supply with flexible generation capacities has been moving increasingly centre stage. On the other

\footnotetext{
* Correspondence: paul.lehmann@ufz.de

${ }^{1}$ Helmholtz Centre for Environmental Research - UFZ, Department of Economics, Permoser Str. 15, 04318 Leipzig, Germany

Full list of author information is available at the end of the article
}

hand, wholesale prices on the electricity exchanges have fallen in the past few years for a variety of reasons [5]. As a result, operators of fossil-fired power plants find themselves facing problems of profitability. Announcements by power plant operators proclaiming that conventional power plants are to be decommissioned or not built at all in the short-to-medium term bear testimony to this development $[3,6]$. Insufficient investment in conventional reserve power plants could - some fear - lead to growing supply bottlenecks in Germany, at the latest with the final shutdown of the last nuclear power plants in 2022. 


\section{Demands for capacity payments and the political agenda}

The introduction of capacity payments for operators of conventional power plants as a way of ensuring the future supply of electricity is currently being debated intensely and controversially. ${ }^{\mathrm{b}}$ Under such a scheme, power plant operators would not only be remunerated for the electricity they produce (in kilowatt hours) - as is the case at the moment - but would also receive an additional payment for the guaranteed capacity they provide (in watts) [7]. The goal of these payments would be to attain a certain level of guaranteed generation capacity. They could also contribute to preventing decommissioning of existing conventional power plants and provide incentives for building new power plants. In principle, storage system operators and electricity consumers who are willing to temporarily cut back on their consumption could conceivably also profit from such payments. In the last two years, various proposals have been drawn up on precisely how the design of such a capacity mechanism for Germany should look [8-12]. The spectrum ranges from the provision of sufficient reserve capacities via the regulatory authority or transmission system operator (strategic reserve) through to more competitively organised mechanisms such as a capacity market. For the purpose of the discussion, it is therefore important to distinguish whether the introduction of a capacity mechanism in general (of whatever design) or a specific capacity market is under consideration. What can be said is that, ultimately, all of the proposed options for a state-initiated capacity mechanism envisage additional payments to power plant operators. In the process, the debate about capacity payments was strongly pushed forward by commissioned reports. At the same time, the topic was placed on the political agenda. For instance, in the coalition agreement, Germany's governing parties declared their intention to 'develop a capacity mechanism in the medium term' ([13], p. 41). The so-called Green Paper entitled 'An Electricity Market for Germany's Energy Transition' published by the German Federal Ministry for Economic Affairs and Energy in October 2014 was aimed at launching a new consultation process in the run-up to the final decision, which is due in the course of this year [14]. Yet, even in the Green Paper, the introduction of a capacity mechanism in the form of a capacity reserve is deemed necessary, at least for a transition period. However, this prior assumption has attracted criticism from scientists and experts.

\section{Current calls for capacity payments are premature}

Basically, the introduction of capacity payments would have far-reaching implications for the future organisation of Germany's energy supply. Decisions to invest in or retire power plants would no longer be (alone) steered by prices on the electricity exchange, which signal scarcities and surpluses in the market. Instead, decisions would be influenced significantly by additional, state-administered capacity payments. The amount of these payments would depend more or less directly on the politically set framework, such as the specified total capacity required. Thus, capacity payments create a new area for government intervention - and possibly also for disincentives set by the state. Furthermore, capacity mechanisms also give rise to fundamental concerns about regulatory policy: For instance, they open up additional possibilities for the state to intervene in the spatial distribution and composition of Germany's power plant fleet. In addition, experience shows that payment flows once created by capacity mechanisms which ultimately can be understood as subsidies ${ }^{\mathrm{d}}$ - can only be taken back with difficulty, even if they lose their potential legitimacy for the energy sector in the future. Hence, the introduction of capacity payments should be carefully considered.

\section{Lack of evidence pointing to a need for capacity payments}

In the context of the discussion on capacity mechanisms, many questions that are crucial to the evaluation of proposals for further developing the current design of the electricity market in a meaningful way have so far remained unanswered. These questions relate not only to the existence of security of supply problems and their underlying causes but also to alternative solution concepts and their respective suitability:

- Will security of supply really be jeopardised in the future if the current regulatory conditions remain in place - or are the current (threatened) retirements of power plants merely the right economic response to existing excess capacity?

- To which market and regulatory failures can potential capacity constraints be attributed? Is security of supply really threatened primarily by the transformation in the energy sector?

- To what extent can capacity mechanisms adequately address the various conceivable causes of possible capacity constraints? And are they suitable to stimulate the required flexible capacities in a targeted manner?

- What negative side effects can capacity payments have? How do they fit at all into an electricity market that is currently taking leave of purely state-administered payments for renewable energy sources?

Then there is also the question as to the potential alternative options to capacity payments. It becomes clear that so far there has been no satisfactory problem diagnosis, nor has the suitability of the presented proposals 
for capacity payments been sufficiently examined. Under these circumstances, the introduction of capacity payments at the present time appears over-hasty and illconsidered. Further scientific analyses of the need for capacity payments, particularly also in the German context - as recently set in motion by the Federal Economics Ministry's Green Paper - are crucial in order to arrive at policy recommendations that will be sustainable in the long term.

\section{Security of supply will not be accomplished alone by building power plants}

The essential starting point for any analysis of capacity payments is a comprehensive, systematic understanding of security of supply. In this light, security of supply should be understood as the permanent balancing of electricity supply and demand, taking into account all possible options for action of market actors. Security of supply cannot be ensured through the construction or continued operation of fossil-fired power plants alone. In fact, in principle, all other actors in the electricity supply system - operators of renewable energy installations, grids and storage systems as well as energy consumers - can contribute to security of supply as well $[15,16]$. In this context, security of supply does not merely mean that the maximum expected energy consumption (taking the possible reduction and flexibilisation potential of demand into account) must be covered by guaranteed generation. Additionally, sufficient flexible capacities must be available in order to be able to respond to short-term, unexpected disruptions in the system so that grid stability can be guaranteed, ideally at all times $[15,17]$.

\section{Security of supply risks should not be minimised at all costs}

A reasonable discussion of measures aimed at ensuring security of supply must consider all societally relevant criteria and objectives. Unquestionably, a certain level of security of supply should be guaranteed at the lowest possible cost. Bearing that in mind, the regulatory framework must be chosen in such a way that, from an economic perspective, the most efficient investments are made - regardless of whether they relate to the construction of new power plants, the expansion of storage systems and grids, demand side management, or a mixture of those options. Furthermore, the question of who would have to shoulder the potential additional costs of greater security of supply has to be examined. What additional burdens would be placed on private households? Would the social debate on energy prices be further intensified? To what extent would the competitiveness of companies be damaged by additional energy costs? And, last but not least, measures aimed at ensuring security of supply must be compatible with the goals of climate protection, the expansion of renewable energy sources and energy efficiency. Possible synergies and conflicts between these various goals must therefore be sufficiently understood and taken into consideration.

\section{No evidence so far for short- or medium-term capacity shortages}

In principle, the electricity market in its current form rewards investments in new power plants and storage systems as well as electricity demand adjustments. The market for balancing energy which ensures short-term stability of the system also rewards particularly flexible options for balancing supply and demand. Theoretically, long-term signals for the construction of power plants or storage systems are sent by the forward markets $[14,18]$. Only the network infrastructure, which by its economic nature represents a natural monopoly, cannot be managed efficiently via the electricity market. The functionality of the electricity market can, however, be additionally impaired for various reasons. Market power, the short-term pursuit of returns on investments or imperfect handling of market uncertainties can affect the efficiency of market actors' decisions. Also, under the current framework conditions, electricity consumers only respond to short-term changes in price signals of electricity scarcity to a limited degree, especially since such changes are frequently not even passed on to the end-user. In addition, the regulatory conditions - such as politically determined price ceilings or lengthy authorisation procedures - can put a brake on investments. ${ }^{e}$ State support for renewable energy sources can exacerbate some of these problems (see the section 'The Energiewende should not be scapegoated for potential supply constraints' below): Support for renewables contributes to decreasing electricity exchange prices and revenues for the operators of conventional power plants [19]. At the same time, support primarily aimed at bringing intermittent energy sources (wind, solar) to the market increases the volatility of energy prices and so contributes to investment uncertainty [20]. Nevertheless, due to the lack of unambiguous empirical evidence, it remains unclear whether and to what extent security of supply might be compromised in the future. Typical indicators suggest that, in principle, there is enough capacity available to cover the maximum expected demand for electricity. Thus, the power account balance, i.e. the balance between (guaranteed) power plant capacity and the maximum demand for electricity, is positive at the moment and probably will be for the coming years $\left([21,22]\right.$, p. $32 \mathrm{f}$.). ${ }^{\mathrm{f}}$ What is more, other European countries have overcapacities and Germany could import more electricity from them. However, some constraints may exist in the short-term balancing of electricity supply and demand, that is, in the flexibility of the electricity supply system. This is perhaps indicated by the Federal Network Agency's prohibition on power plant shutdowns and the call-up of the grid reserve for redispatch purposes ([22], p. 41 f.; [23]). Nevertheless, 
these measures are more likely an expression of grid constraints than of insufficient generation capacity [24].

\section{It is doubtful that capacity payments can help to solve the problem}

Capacity payments, when adequately designed, can without doubt serve as an effective means of achieving a certain level of guaranteed capacity. Other countries' experiences with capacity mechanisms are nonetheless quite conflicting $[25,26]$. Yet it is less clear whether capacity payments can activate precisely those options that are flexible enough to balance supply and demand - such as flexible fossil-fired power plants, storage systems or demand side management. Additional pre-qualification requirements for the granting of capacity payments - as envisaged by some but by no means all of the proposed models - must be established to ensure this.

Capacity mechanisms, as simple, state-administered payments without a time limit, also give rise to regulatory policy issues. For instance, it remains to be clarified how capacity payments should be evaluated in respect of the equally relevant energy policy objectives of economic efficiency and environmental and social acceptability. Essentially, capacity payments only address the actual causes of possible security of supply problems to a limited extent that is, the various existing market and regulatory deficits (see the section 'No evidence so far for short- or mediumterm capacity shortages' above). Moreover, in the future, capacity payments - particularly when institutionalised through an entirely new 'capacity market' - can only be adjusted to changing circumstances, or even fundamentally revised, with difficulty. After all, it is to be expected that the future recipients of payments would have a vested interest in maintaining the payments and that they would assert their interest politically. The distributional implications of capacity payments also remain unclear: if they result in rising energy prices, capacity payments will give rise to a substantial redistribution of income from the electricity consumers to the electricity suppliers operating the power plants [27]. Social and industrial policy concerns have frequently been expressed in connection with the expected price effects caused by the promotion of renewable energy sources. Such concerns must therefore also be taken into consideration in the case of novel and tendentially unlimited payments for conventional power plant capacities. Ultimately, we also have to ask whether new payments for existing fossil-fired installations would not essentially complicate the transition to a more sustainable electricity supply, which in the year 2050 is supposed to be based predominantly on renewable energy sources. After all, capacity payments would possibly incentivise the construction of new fossil-fired power plants which would be in existence over several decades to come. This applies in particular if the EU emissions trading scheme is not sufficiently strengthened.

\section{Strengthening of existing structures should have priority}

At the same time, there are alternatives to capacity payments. Security of supply can also be guaranteed through a mix of instruments. For example, measures aimed at strengthening the existing electricity market could make a contribution. Possible options range from the completion of deregulation of the electricity market (in order to contain market power and make price ceilings redundant) to regionally differentiated wholesale prices (for better signalling of regional capacity constraints) right through to accelerated authorisation procedures for building new infrastructure $[14,18,28]$. In the area of energy transformation policy, incentives for a more demand-based feed-in of electricity from renewable energy sources could be set [29-32]. A fundamental strengthening of the emissions trading scheme would also shift investment decisions in the power plant sector towards gas power plants with lower emission and greater flexibility. In addition, targeted measures could set incentives for the construction and operation of grids, storage systems and demand side management. In this case, too, the imaginable portfolio is broad, ranging from adjustments to incentive regulation for networks through to support for technology and research relating to battery storage and smart grids [33-35].

From an economic perspective, a mix of instruments aimed at addressing the various causes of insufficient security of supply can lead to lower macroeconomic costs than fixed capacity payments. Furthermore, some of the instruments would also confer other advantages in addition to security of supply. For example, a tightening of the emissions trading scheme would also enhance the effectiveness of climate protection policy. The additional administrative burden of such a mix of instruments is likely to be limited: Many of the possible alternatives for ensuring security of supply have already been implemented and require strengthening and realignment more than anything else. But by nature such a mix of instruments is not without its problems. Given the high regulatory complexity involved, the combined measures must be carefully coordinated to complement each other. Moreover, the ultimate distribution effects in the mix of policy instruments are difficult to predict. And whether a combination of measures can actually be more flexibly adapted to changing framework conditions than centrally administered capacity payments is also questionable.

\section{The Energiewende should not be scapegoated for potential supply constraints}

The impression often arising from the current debate on security of supply is that potential problems can be attributed 
primarily to the Energiewende - that is, the promotion of renewable energy sources and the phase-out of nuclear power. Without a doubt, the increasing share of (intermittent) renewable energy sources, especially wind and solar energy, in electricity generation as a whole creates additional challenges for ensuring security of supply $[20,15,17,19]$. Nevertheless, a differentiated look at the framework conditions under which the electricity market operates today (see the section 'No evidence so far for short- or medium-term capacity shortages' above) also shows that the Energiewende is just one of numerous causes of possible supply constraints. Many of the challenges mentioned (e.g. short-term profit maximisation under uncertainty or low demand response) would also arise without the energy transition. Furthermore, in the medium-term market, actors will respond to the energy transition, even without state intervention, and will take measures conducive to ensuring security of supply. So, the support of renewable energy sources increases end consumer prices and therewith sets additional incentives for reducing electricity demand. When nuclear power plants are shut down, operating times and revenues for fossil-fired power plants go up in the medium term [36]. Therefore, it is clear that adjustments, particularly to support schemes for renewable energy sources, have to be taken into consideration as a way of helping to secure supply in the long term. The Energiewende is not, however, the sole 'scapegoat' for possible future supply constraints. And it would certainly not be prudent to put the Energiewende on the back burner in the interest of security of supply.

\section{An intelligent portfolio of measures instead of capacity payments for fossil-fired power plants}

The debate on security of supply symbolises the complexity and manifold uncertainties associated with Germany's Energiewende. Particularly under these circumstances, from a scientific perspective, it is important at this point not to make far-reaching and profound decisions such as introducing novel, permanent regulatory instruments in the absence of clear evidence. It would appear to make more sense to have a security of supply policy that stands on many legs. A portfolio of measures can help to tackle the diverse causes of possible capacity constraints in a more targeted and cost-effective manner. In doing so, given the complexity and uncertainty involved, it is important that the political process is designed to be as transparent and participatory as possible so that the perspectives of all the relevant actors - including those of electricity suppliers, grid and storage system operators and, not least, energy consumers - can be given due consideration [37]. In addition, the political instruments must be chosen such that they can be adapted to future changing framework conditions. For political reasons, this seems rather unlikely once capacity payments have been granted.

\section{Credible political commitment needed}

Admittedly, a political strategy aimed at ensuring security of supply without capacity payments can only work if policy makers can give credible assurances that a capacity mechanism will not be introduced in the foreseeable future. Otherwise a self-fulfilling prophecy threatens: in expectation of possible future capacity payments, companies might see themselves incentivised to strategically hold off on investments and, with the announcement of power plant shutdowns, create a political threat. Ultimately, even just the political prospect of a future possibility of a capacity mechanism would in the end make it politically inevitable due to this strategic withholding of investment [38].

\section{A strategic reserve as a risk buffer?}

It is the task of policy makers to evaluate the established uncertainties with regard to ensuring the supply of electricity and to make decisions on this basis. Therefore, it would be politically legitimate if, following careful and transparent consideration, political decision makers were to conclude that additional capacity-building measures are essential to safeguard against possible supply constraints. But in this case, given the current knowledge gaps, it would be crucial that the mechanism be selected in such a way that less rigid structures emerge in the future which - with better evidence of the performance capacity of conventional electricity markets and a clear understanding of the advantages and disadvantages of various measures - would be difficult to adjust. Therefore, if a decision in favour of capacity payments is made at political level, then efforts should be made to ensure a strategic, centrally administered capacity reserve (strategic reserve) as a short- and medium-term risk buffer. This approach could provide the required flexible capacities in a targeted manner. What is more, it could be reversed at any time.

The Green Paper on the electricity market calls for a fundamental policy decision between an optimised 'electricity market 2.0' embedded in a package of measures aimed at strengthening flexibility and securing supply on the one hand, and extra payments for conventional power plants in the sense of a capacity market on the other ([14], p. 40). Considering the various uncertainties, there is apparently more to be said for the first option at present. A package of measures could address the diverse causes of possible supply bottlenecks in a more targeted manner and at the same time take better account of the requirements of economic efficiency and environmental and social acceptability. The introduction of a strategic reserve can - depending on the political assessment of the threat to security of supply - be among the flanking measures accompanying the 'electricity 
market 2.0'. The short-term introduction of complex capacity markets for conventional power plants, on the other hand, would fail to address the root causes of supply bottlenecks, neglect important objectives of sustainable energy policy and, in addition, lead to a specific predetermined solution that would be difficult, if not impossible, to revise in a regulatory environment that is on the whole uncertain. Therefore, based on our current knowledge, capacity markets of this kind are not recommended.

\section{Endnotes}

${ }^{a}$ This article is based on a detailed discussion paper, see [39].

${ }^{\mathrm{b}} \mathrm{See}$ numerous studies which either propose capacity mechanisms [8-12] or question the need for them $[18,20,27,38,40-43]$.

${ }^{\mathrm{c}} \mathrm{See}$, e. g. $[18,20,27,38,40-43]$.

${ }^{\mathrm{d}}$ From an economic perspective, it is important to determine whether capacity payments lead to welfare gains and to what extent redistribution takes place. In addition, whether capacity payments constitute state aid has to be legally clarified; see for instance [14].

${ }^{\mathrm{e}}$ For an overview of possible causes, see $[7,18]$.

f On the expected future development, see also [44].

\section{Competing interests}

The authors declare that they have no competing interests.

\section{Authors' contributions}

Several authors drafted the first version of this manuscript. All authors contributed to revise and finalise this article. All authors read and approved the final manuscript.

\section{Authors' information \\ The authors jointly conduct research in the Alliance ENERGY-TRANS established by the Helmholtz Association of German Research Centers. Alliance researchers examine the energy transition in Germany and the related demands it places on the transformation of the national and European energy system, especially from the perspective of societal demand and utility, and analyse the manifold interfaces between technical and social factors. The results should provide policy-oriented know-how for an efficient and socially acceptable organisation of the future energy system. Further information can be found at www.energy-trans.de.}

\begin{abstract}
Author details
${ }^{1}$ Helmholtz Centre for Environmental Research - UFZ, Department of Economics, Permoser Str. 15, 04318 Leipzig, Germany. ${ }^{2}$ Environmental Policy Research Center (FFU), Freie Universität Berlin, Ihnestraße 22, 14195 Berlin, Germany. ${ }^{3}$ Institute for Infrastructure and Resources Management, Leipzig University, Grimmaische Str. 12, 04109 Leipzig, Germany. ${ }^{4}$ Center for European Economic Research (ZEW), L7, 1, 68034, Mannheim, Germany. ${ }^{5}$ School of Business and Economics, Chair for Microeconomics, esp. Energy and Resource Economics, Westfälische Wilhelms-Universität Münster, Am Stadtgraben 9, 48143 Münster, Germany. ${ }^{6}$ Institute of Technical Thermodynamics, German Aerospace Center (DLR), Pfaffenwaldring 38-40, 70569 Stuttgart, Germany. ${ }^{7}$ Stuttgart Research Center for Interdisciplinary Risk and Innovation Studies (ZIRIUS), University of Stuttgart, Seidenstr. 36, 70174 Stuttgart, Germany.
\end{abstract}

Received: 19 February 2015 Accepted: 24 February 2015 Published online: 29 April 2015

\section{References}

1. Mundt A (2012) Wettbewerb ist der Schlüssel zur Energiewende, Frankfurter Allgemeine Online, 20 July 2012, http://www.faz.net/aktuell/politik/energiepolitik/ energiepolitik-wettbewerb-ist-der-schluessel-zur-energiewende-11825402.html. Accessed 16 Feb 2015.

2. Spiegel Online (2014) Teyssen hält Atom- und Kohlestrom für kaum profitabel, 18 March 2014, http://www.spiegel.de/wirtschaft/soziales/e-on-chef-teyssen-haeltatom-und-kohlestrom-fuer-kaum-profitabel-a-958458.html. Accessed 16 Feb 2015.

3. Süddeutsche Zeitung (2014) Ausgepowert - Streit um Finanzhilfen: Deutschlands zweitgrößter Energiekonzern RWE erwägt die Stilllegung weiterer Kraftwerke. Süddeutsche Zeitung 12 Aug 2014:19.

4. Bundesministerium für Wirtschaft und Energie [German Federal Ministry for Economic Affairs and Energy] (2014) Zeitreihen zur Entwicklung der erneuerbaren Energien in Deutschland unter Verwendung von Daten der Arbeitsgruppe Erneuerbare Energien-Statistik. AGEE-Stat. Bundesministerium für Wirtschaft und Energie, Berlin

5. Mayer JN, Burger B (2014) Kurzstudie zur historischen Entwicklung der EEG-Umlage. Fraunhofer ISE, Freiburg

6. Financial Times Deutschland Online (2012) Energiewende: Eon stoppt Pläne für Gaskraftwerke., 23 Aug 2012.

7. Cramton P, Ockenfels A (2012) Economics and design of capacity markets for the power sector. Zeitschrift für Energiewirtschaft 36(2):113-134

8. Bundesverband der Deutschen Energie- und Wasserwirtschaft [BDEW] [German Association of Energy and Water Industries] (2013) Ausgestaltung eines dezentralen Leistungsmarkts. Position Paper, BDEW, Berlin

9. Enervis BET (2013) Verband Kommunaler Unternehmen [VKU] (2013) Ein zukunftsfähiges Energiemarktdesign für Deutschland. Enervis, BET, VKU, Berlin

10. Energiewirtschaftliches Institut an der Universität zu Köln [EWI] (2012) Untersuchung zu einem zukunftsfähigen Strom-Marktdesign. Energiewirtschaftliches Institut an der Universität zu Köln, Köln

11. Öko-Institut LBD, Raue LLP (2012) Fokussierte Kapazitätsmärkte - Ein neues Marktdesign für den Übergang zu einem neuen Energiesystem. Öko-Institut, LBD, Raue LLP, Berlin

12. $\quad$ 2b (2012) Ziele und Ausgestaltung einer Strategischen Reserve. Eckpunktepapier. r2b, Berlin

13. CDU, CSU, SPD (2013) Deutschlands Zukunft gestalten, Koalitionsvertrag zwischen CDU. CSU und SPD, 18. Legislaturperiode, Berlin, http:// www.bundesregierung.de/Content/DE/_Anlagen/2013/2013-12-17koalitionsvertrag.pdf?__blob=publicationFile. Accessed 16 Feb 2015

14. Bundesministerium für Wirtschaft und Energie [German Federal Ministry for Economic Affairs and Energy] (2014) An electricity market for Germany's energy transition, Discussion Paper of the German Federal Ministry for Economic Affairs and Energy (Green Paper). Bundesministerium für Wirtschaft und Energie, Berlin

15. Gottstein M, Skillings S (2011) Über Kapazitätsmärkte hinausdenken: Flexibilität als Kernelement. Energiewirtschaftliche Tagesfragen 62(11):18-25

16. Beckers T, Hoffrichter A (2014) Grundsätzliche und aktuelle Fragen des institutionellen Stromsektordesigns - Eine institutionenökonomische Analyse zur Bereitstellung und Refinanzierung von Erzeugungsanlagen mit Fokus auf FEE. Technische Universität Berlin. Fachgebiet Wirtschafts- und Infrastrukturpolitik (WIP), Berlin

17. Reeg M (2014) Entwurf eines ganzheitlichen Marktdesign für hohe Anteile erneuerbarer Energien, Diskussionspapier der Abteilung Systemanalyse und Technikbewertung. DLR-Institut für Technische Thermodynamik, Stuttgart

18. Economics F (2014) Strommarkt in Deutschland - Gewährleistet das derzeitige Marktdesign Versorgungssicherheit? Frontier Economics, London

19. Traber T, Kemfert C (2011) Gone with the wind? - Electricity market prices and incentives to invest in thermal power plants under increasing wind energy supply. Energy Econ 33(2):249-256

20. Böckers V, Giessing L, Haucap J, Heimeshoff U, Rösch J (2012) Braucht Deutschland einen Kapazitätsmarkt für Kraftwerke? Eine Analyse des deutschen Marktes für Stromerzeugung, Ordnungspolitische Perspektiven Nr. 24. Düsseldorfer Institut für Wettbewerbsökonomie, Düsseldorf, http:// www.dice.hhu.de/fileadmin/redaktion/Fakultaeten/Wirtschaftswissenschaftliche_ Fakultaet/DICE/Ordnungspolitische_Perspektiven/024_OP_Bo_ckers_Giessing_ Haucap-Heimeshoff_Ro_sch.pdf. Accessed 16 Feb 2015

21. 50hertz, Amprion, Tennet, Transnet BW (2013) Bericht der deutschen Übertragungsnetzbetreiber zur Leistungsbilanz 2013 nach EnWG § 12 Abs. 4 und 5. N. p.

22. Bundesnetzagentur [German Federal Network Agency], Bundesnetzagentur [German Federal Network Agency], Bundeskartellamt [German Federal Cartel Office] (2013) Monitoringbericht 2013. Bundesnetzagentur. Bundeskartellamt, Bonn 
23. Bundesnetzagentur [German Federal Network Agency] (2013) Bericht zum Zustand der leitungsgebundenen Energieversorgung im Winter 2012/13. Bonn, http://www.bundesnetzagentur.de/SharedDocs/Downloads/DE/ Allgemeines/Bundesnetzagentur/Publikationen/Berichte/2013/ 130620_Netzbericht_Winter2012-2013.pdf?_blob=publicationFile\&v=9. Accessed 17 Feb 2015.

24. Deutsches Zentrum für Luft- und Raumfahrt [DLR], Institut für Energiewirtschaft und Rationelle Energieanwendung [IER] der Universität Stuttgart (2014) Kurzstudie zur Kapazitätsentwicklung in Süddeutschland bis 2025 unter Berücksichtigung der Situation in Deutschland und den europäischen Nachbarstaaten, Im Auftrag des Ministeriums für Umwelt. Klima und Energiewirtschaft Baden-Württemberg, Stuttgart, https:/um.baden-wuerttemberg.de/fileadmin/redaktion/m-um/intern/ Dateien/Dokumente/5_Energie/Nersorgungssicherheit/Kurzstudie_Kapazitaetsent wicklung_Sueddeutschland.pdf. Accessed 17 Feb 2015

25. Beckers T, Hoffrichter A, von Hirschhausen C (2012) Internationale Erfahrungen mit Kapazitätsinstrumenten und Schlussfolgerungen für die deutsche Diskussion. Technische Universität Berlin. Fachgebiet Wirtschafts- und Infrastrukturpolitik (WIP), Berlin

26. Süßenbacher W, Schwaiger M, Stigler H (2011) Kapazitätsmärkte und-mechanismen im internationalen Kontext, 7. Internationale Energiewirtschaftstagung an der TU. Wien, Wien

27. Frontier Economics, Consentec (2014) Folgenabschätzung Kapazitätsmechanismen (Impact Assessment). Frontier Economics, Consentec, London

28. Löschel A, Flues F, Pothen F, Massier P (2013) Den Strommarkt an die Wirklichkeit anpassen - Skizze einer neuen Marktordnung. Energiewirtschaftliche Tagesfragen 63(10):22-25

29. Gawel E, Purkus A, Korte K, Lehmann P (2013) Förderung der Markt- und Systemintegration erneuerbarer Energien - Perspektiven einer instrumentellen Weiterentwicklung. Vierteljahreshefte zur Wirtschaftsforschung 82(3):123-136

30. Gawel E, Purkus A (2013) Promoting the market and system integration of renewable energies through premium schemes - a case study of the German market premium. Energy Policy 61:599-609

31. Purkus A, Gawel E, Deissenroth M, Nienhaus K, Wassermann S (2014) Der Beitrag der Marktprämie zur Marktintegration erneuerbarer Energien - Erfahrungen aus dem EEG 2012 und Perspektiven der verpflichtenden Direktvermarktung. Energiewirtschaftliche Tagesfragen 64(12):8-16

32. Purkus A, Gawel E, Deissenroth M, Nienhaus K, Wassermann S (2015) Market integration of renewable energies through direct marketing - lessons learned from the German market premium scheme. Energy, Sustainability and Soc 5:12, doi:10.1186/s13705-015-0040-1

33. Achtnicht M, Madlener R (2014) Factors influencing German house owners' preferences on energy retrofits. Energy Policy 68:254-263

34. Kastner I, Matthies E (2014) Implementing web-based interventions to promote energy efficiency behavior at organizations - a multi-level challenge. J Clean Prod 62:89-97

35. Korte K, Gawel E (2015) Power grid investments and incentive regulation: problem areas and solution approaches. Wirtschaftsdienst 95(2):127-134

36. Knopf B, Pahle M, Kondziella H, Joas F, Edenhofer O, Bruckner T (2014) Germany's nuclear phase-out: sensitivities and impacts on electricity prices and $\mathrm{CO}_{2}$ emissions. Econ Energy Environ Policy 3(1):89-105

37. Wassermann S, Renn O (2013) Open questions of the German Energiewende: setup and design of capacity management for the German electricity market. GAIA 22(4):237-241

38. Gawel E, Korte K (2014) Das Grünbuch Strommarktdesign: Subventionen für konventionelle Kraftwerke ante portas? WISO direkt 2014(12), Dec 2014, http://library.fes.de/pdf-files/wiso/11080.pdf. Accessed 16 Feb 2015.

39. Reeg M, Brandt R, Gawel E, Lehmann P, Korte K, Heim S, Massier P, Schober D, Wassermann S (2015) Kapazitätsmechanismen als Rettungsschirm der Energiewende? Zur Versorgungssicherheit bei hohen Anteilen fluktuierender Erneuerbarer, Helmholtz Alliance ENERGY-TRANS Discussion Paper 2015 (1), http://www.energy-trans.de/downloads/ENERGY-TRANS-DPKapazitaetsmechanismen.pdf. Accessed 16 Feb 2015.

40. Connect (2014) Leitstudie Strommarkt: Arbeitspaket Optimierung des Strommarktdesigns. Connect, Berlin

41. Deutsches Institut für Wirtschaftsforschung [DIW] (2013) Sicherung der Stromversorgung, DIW Wochenbericht 2013(48). DIW, Berlin

42. Nicolosi M (2012) Notwendigkeit und Ausgestaltungsmöglichkeiten eines Kapazitätsmechanismus für Deutschland, Report of the German Federal Environment Agency [UBA] Climate Change 2012(12). Umweltbundesamt, Dessau-Roßlau
43. Winkler J, Keles D, Renz L, Sensfuß F, Fichtner W (2013) Perspektiven zur aktuellen Kapazitätsmarktdiskussion in Deutschland. Zeitschrift für Energiewirtschaft 37(4):233-248

44. Agentur für erneuerbare Energien [German Renewable Energies Agency] (2013) Studienvergleich. Bedarf an steuerbaren Kapazitäten im Stromsystem, Berlin, http://www.forschungsradar.de/uploads/media/AEE_Dossier_ Studienvergleich_Versorgungssicherheit_dez13.pdf. Accessed 16 Feb 2015

\section{Submit your manuscript to a SpringerOpen ${ }^{\odot}$ journal and benefit from:}

- Convenient online submission

- Rigorous peer review

- Immediate publication on acceptance

- Open access: articles freely available online

- High visibility within the field

- Retaining the copyright to your article

Submit your next manuscript at $>$ springeropen.com 